\title{
Organic Fertilizer Potential Using Aspergillus niger, Pseudomonas putida and Effective Microorganisms from Coconut Water Waste in Ponorogo, East Java - Indonesia
}

Raden Darmawan*, Sri Rachmania Juliastuti, Nuniek Hendrianie, Setiyo Gunawan, Hakun Wirawasista Aparamarta, Reynad D.P. Gultom, Rillya Kharisma Prabatiwi

Department of Chemical Engineering, Faculty of Industrial Technology, Institut Teknologi Sepuluh Nopember, 60111 Surabaya, INDONESIA

\begin{abstract}
The abundance of coconut water as a waste of household industry activities in Ponorogo can be obtained. There is still organic matter considered to become a liquid fertilizer where it can be expected to substitute for the use of inorganic fertilizers. The research aims to determine the potential of coconut water as a liquid organic fertilizer involving three types of microorganisms, such as Aspergillus niger, Pseudomonas putida and Effective Microorganisms (EM4). The experiment was conducted using a mixed bacth reactor with $4 \mathrm{~L} /$ minute of aeration rate and initial microorganism 's number of approximately $10^{7}$ cells/ mL for 10 days. The results suggest that the highest reduction of $\mathrm{C}$-organic and the biggest enhancement of $\mathrm{N}, \mathrm{P}, \mathrm{K}$ can be achieved by a combination of $A$. niger and $P$. putida with $29 \% ; 100 \%, 110 \%, 552 \%$, respectively.
\end{abstract}

\section{Introduction}

Use of inorganic fertilizers excessively can worsen the physical condition of the soil. It can reduce the number of soil's nutrients and minerals. Furthermore, it also can break down the soil structure. In order to improve and maintain the sustainable use of soils, the utilization of organic fertilizer is a way to meet them. The organic fertilizers suppose to heal the texture of soil by resupplying the nutrients and minerals lost.

Ponorogo is an industrial center of micro, small, and medium scale business (UMKM) for several household processed products, including traditional food products (Jenang). In this production, UMKM produces coconut water which is not utilized properly or even thrown away. The utilization of this waste of coconut water needs to be captured as a potential challenge where nutrients present in the wastewater recovered optimally to generate beneficial products to the community. One of an appropriate method is by making organic liquid fertilizer (POC) from wastewater of coconut that can be used as substitutes of synthetic fertilizers. There are economic and ecological advantages found to be higher when the wastewater of coconut fermented become POC. Future perspectives indicate that it will be one of greatest challenges of nutrient variability to utilize the waste become biobased fertilizer products [1]. It is well known that bio-based fertilizers have high variability in nutrient composition $[2,3]$. The existence of POC can be used to fertilize plants and supply organic materials to improve the physical, chemical, and biological properties of the soil. On the other hand, the use of excessive inorganic fertilizers during this time can worsen the physical condition of the soil, so the need for the development of organic fertilizer.

The research was conducted to find out the used microorganisms appropriately to apply to chilies, tomatoes, and eggplants. Aspergillus niger, Pseudomonas putida and bio-activator EM4 were several microorganisms to be variables for generating organic fertilizers from coconut water waste.

\section{Materials and Methods}

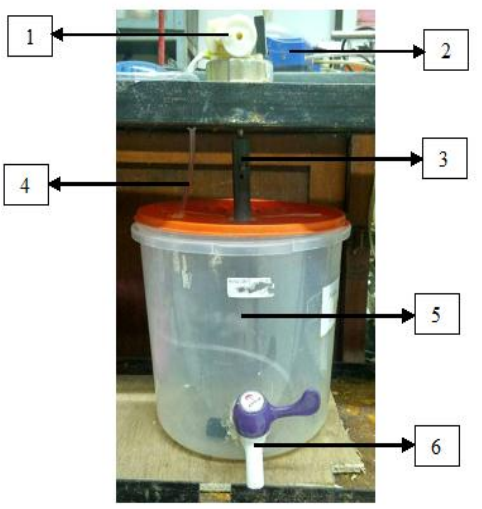

Information:

1. Dynamo agitator

2. Aerator

3. Agitator

4. Air hose

5. Reactor

6. Output valve

Fig. 1. Mixed Batch Reactor

The organic fertilizers from coconut water waste were produced through fermentation process by implementing

\footnotetext{
*Corresponding author: rdarmawan@chem-eng.its.ac.id
} 
several microorganisms. They were Aspergillus niger, Pseudomonas putida and bio-activator EM4 as a starter with initial number $10^{7} / \mathrm{mL}$. The fermentation was conducted using a mixed batch reactor (Fig.1) with an aeration rate of $4 \mathrm{~L} /$ minutes for 10 days. A number of macronutrients $(\mathrm{N}, \mathrm{P}, \mathrm{K}$, and $\mathrm{C}$-organic) were analyzed before process fermentation started, after the $5^{\text {th }}$ day and the $10^{\text {th }}$ day. The concentration number of macronutrients before the process can be seen in Table 1 as follows.

Table 1. Initial number (\%) of $\mathrm{N}, \mathrm{P}, \mathrm{K}$ and $\mathrm{C}$ before fermentation periods.

\begin{tabular}{|c|l|c|c|c|c|}
\hline \multirow{2}{*}{ No } & \multirow{2}{*}{ Variable } & \multicolumn{4}{|c|}{ Nutrient (\%) } \\
\cline { 3 - 6 } & & $\mathrm{N}$ & $\mathrm{P}$ & $\mathrm{K}$ & $\mathrm{C}$ \\
\hline 1 & $P$. putida & 0.02 & 0.01 & 0.018 & 0.65 \\
\hline 2 & A. niger & 0.02 & 0.01 & 0.018 & 0.65 \\
\hline 3 & EM4 & 0.02 & 0.01 & 0.018 & 0.65 \\
\hline 4 & $\begin{array}{l}\text { P.putida }: \text { A. } \\
\text { niger }\end{array}$ & 0.02 & 0.01 & 0.018 & 0.65 \\
\hline 5 & EM4 : P.putida & 002 & 0.01 & 0.018 & 0.65 \\
\hline 6 & EM4 : A.niger & 0.02 & 0.01 & 0.018 & 0.65 \\
\hline 7 & $\begin{array}{l}\text { EM4 : P. putida : } \\
\text { A. niger }\end{array}$ & 0.04 & 0.01 & 0.015 & 1.19 \\
\hline 8 & Negative Control & 0.04 & 0.01 & 0.015 & 1.19 \\
\hline
\end{tabular}

The produced biofertilizers were applied to manure three type of plants (chilies, tomatoes, and eggplants) for 45 days. The plants were measured and observed for initial height ( 0 days) and conditions, respectively before spraying the liquid organic fertilizer into the tested plants. The fertilization stage was conducted every two days using $10 \mathrm{~mL}$ of each variable then diluted with sterile water up to $20 \mathrm{~mL}$ previously. Some physicals development were also investigated such as the hight of plant and the presence and colour of fruit to evaluate the effect of some microorganisms mixtures.

\section{Result and Discussion}

In this experiment, the macronutrients $(\mathrm{N}, \mathrm{P}, \mathrm{K}$, and $\mathrm{C}$ organic) were investigated.

\section{Increasing of Nitrogen Element}

The fermentation process was carried out for 10 days because all variables implemented had increased at the period especially nitrogen content. As shown in Fig. 2, the mixture of Pseudomonas putida and Aspergillus niger reported that it had the highest increase of nitrogen compound $(100 \%)$. Two types of microorganisms believed can improve and have a critical role as the contributors for the nitrogen composition on the plants [4]. Pseudomonas putida and Aspergillus niger are belonging to diazotroph microorganisms where the microorganisms have an important role to fix nitrogen. The capability of the microorganisms might be the present a nitrogenase enzyme which capable of combining hydrogen and nitrogen $[5,6]$. The results also appropriate with [7] that the content of nitrogen can be increased by the fermentation process.

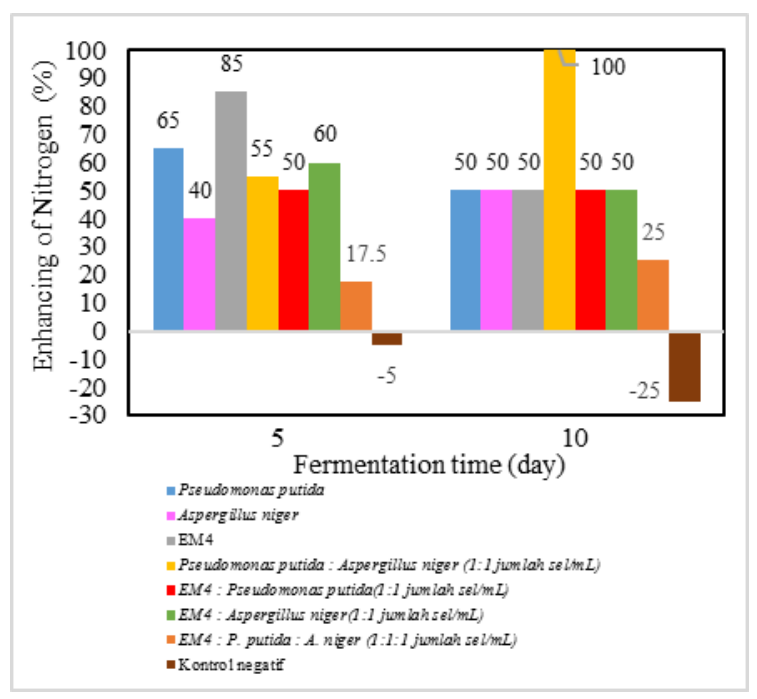

Fig. 2. Percentage increasing of nitrogen element

\section{Increasing of Phosphor Element}

The enhancing of phosphor elements were decreased with increasing fermentation time. For 5 days period, the greatest content can be achieved (300\%) then the composition was decreased $(110 \%)$ for 10 days fermentation period. The results were shown in Fig. 3 by implementing the combination of Pseudomonas putida and Aspergillus niger. The microorganisms are not suitable for increasing phosphor element [4].

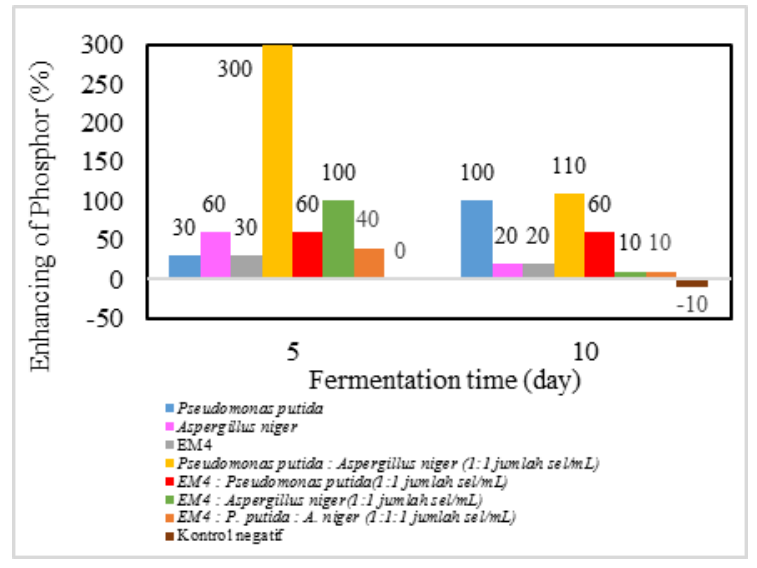

Fig. 3. Percentage increasing of phosphor element

The result is consistent with [4] which present that along with the fermentation process in organic fertilizers, the phosphor contents would also increase although not significantly.

\section{Increasing of Potassium Element}

Potassium contents were enhanced along with the fermentation experiment carried out after time 5 days then for several variables were decreased after 10 days period. 


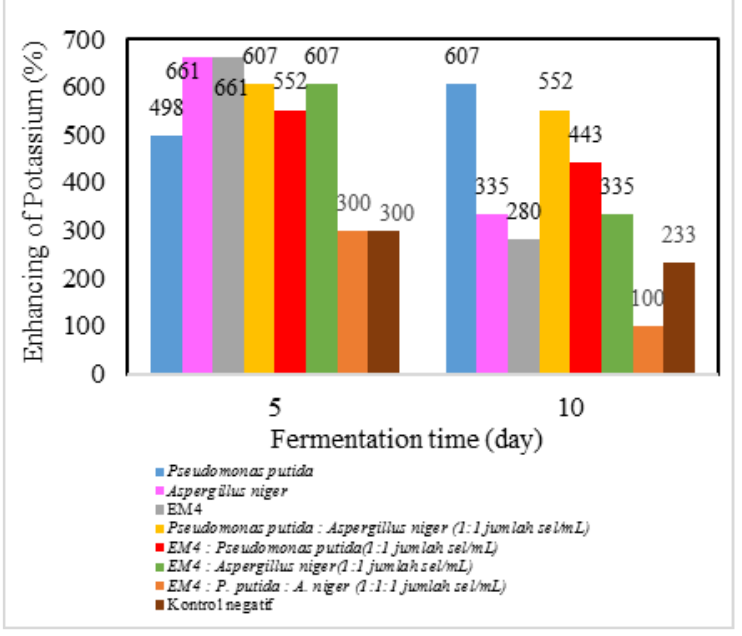

Fig. 4. Percentage increasing of Potassium element

The highest result was obtained by Pseudomonas putida $(607 \%)$ then followed by the combination of Pseudomonas putida and Aspergillus niger (552\%). The increasing of $\mathrm{K}$ element may be caused by the reaction of hydrolysis and proteolysis that is the loss of $\mathrm{K}^{+}$from the origin mineral of organic matter.

\section{Decreasing of Carbon Element}

In the experiment, the carbon compounds were breaked down into a simple element with more stable. All variables demonstrated decreased with increasing the fermentation period except the negative control was increased. The condition may be caused by the absence of the supplemented microorganisms that utilize Corganic within coconut water as a carbon source to increase the metabolism of microorganisms.

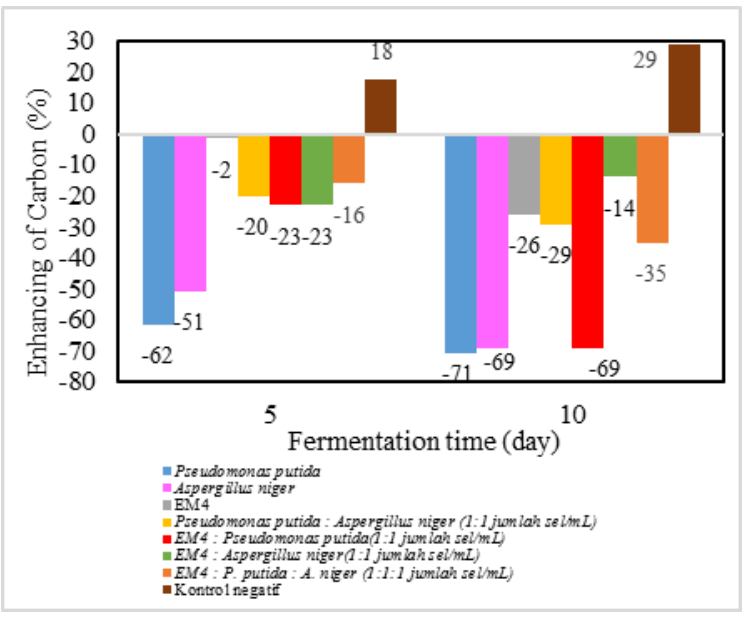

Fig. 5. Percentage increasing of Carbon element

Generally, based on the results of research that the highest levels of macro nutrient are variables using the mixtures of Pseudomonas putida and Aspergillus niger in which it can increase N, P, and K elements of $100 \%$, $110 \%$, and $552 \%$, respectively.

\section{Application the biofertilizer on the tested plants}

Three types of plants were selected to evaluate the produced biofertilizer. The fertilizer was used to manure the plants. The response plants were also observed for the initial time, 15, 30, and 45 days, including high growth (Table 2) and physical development (leaves and fruits) of plants (Fig. 6, 7, 8) using the mixture of Pseudomonas putida and Aspergillus niger.

Table 2. Difference of height $(\mathrm{cm})$ on the tested plants after manuring for 45 days

\begin{tabular}{|c|l|c|c|c|}
\hline \multirow{2}{*}{ No } & \multirow{2}{*}{ Variable } & \multicolumn{3}{c|}{$\Delta \mathrm{h}=\mathrm{h}_{45}$ day $-\mathrm{h}_{0}$ day $(\mathrm{cm})$} \\
\cline { 3 - 5 } & & Chilli & Tomato & Eggplant \\
\hline 1 & EM4 & 8.67 & 5 & 7.33 \\
\hline 2 & Pseudomonas putida & 10 & 5 & 7.17 \\
\hline 3 & Aspergillus niger & 8.33 & 5.5 & 7 \\
\hline 4 & $\begin{array}{l}\text { EM4 }: \text { Pseudomonas } \\
\text { putida }\end{array}$ & 8.17 & 5.5 & 7.5 \\
\hline 5 & EM4 : Aspergillus niger & 9.17 & 5.5 & 7 \\
\hline 6 & $\begin{array}{l}\text { Pseudomonas putida : } \\
\text { Aspergillus niger }\end{array}$ & 10.5 & 6 & 7.67 \\
\hline 7 & $\begin{array}{l}\text { EM4: Pseudomonas } \\
\text { putida : Aspergillus niger }\end{array}$ & 8.33 & 5.33 & 7 \\
\hline 8 & Negative Control & 6.33 & 4.5 & 6 \\
\hline 9 & Water only & 5.67 & 3.67 & 5.33 \\
\hline
\end{tabular}

The best of the height difference was obtained using the liquid organic fertilizer with the addition of the mixture of Pseudomonas putida and Aspergillus niger. From Table 2, it can be summarized that the highest of differences from the tested plants of chilies, tomatoes, and eggplants were $10.5 \mathrm{~cm}, 6 \mathrm{~cm}$, and $7.67 \mathrm{~cm}$, respectively.

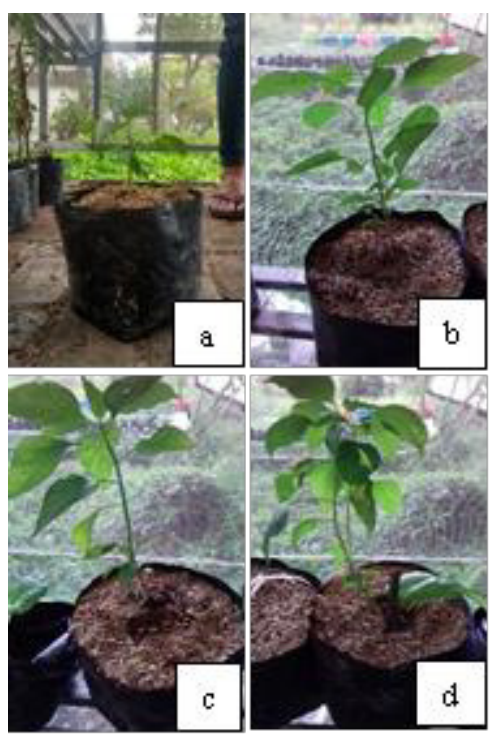

Fig. 6. Testing biofertilizer to manure on chilies for (a) initial; (b) 15 days; (c) 30 days; (d) 45 days

The results indicate that the combination of Pseudomonas putida and Aspergillus niger is suitable microorganisms for generating the liquid organic 
fertilizer from coconut water waste. On the observation of fruit development, that the tested plants showed the different responses of each variable. The most rapid development was shown by the tested plants using the liquid organic fertilizer with the mixture of Pseudomonas putida and Aspergillus niger supplemented. The results are confirmed physically in which the development of fruit that has changed color (mature) after 45 days at Fig. 7(d).

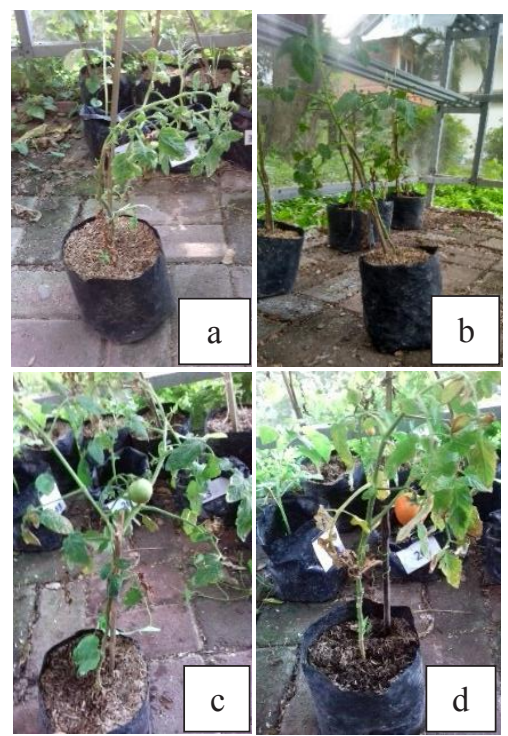

Fig. 7. Testing biofertilizer to manure on tomatoes for (a) initial; (b) 15 days; (c) 30 days; (d) 45 days

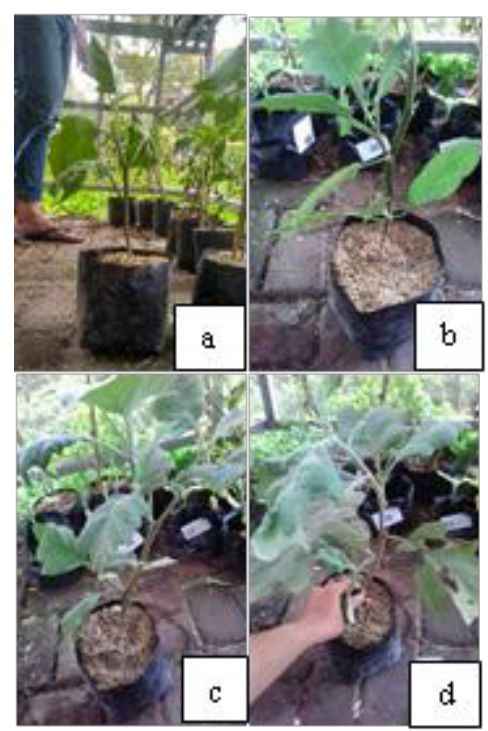

Fig. 8. Testing biofertilizer to manure on eggplants for (a) initial; (b) 15 days; (c) 30 days; (d) 45 days

The experiment results provide that the microorganisms composition using the mixture of both Pseudomonas putida and Aspergillus niger can produce the most effective of organic liquid fertilizer from the coconut water waste than using other microorganisms.

\section{Conclusion}

From the research can be concluded that

1. The bioreactor system described here is a promising alternative method for producing biofertilizer.

2. The coconut waste water can be used as the potential material source for generating liquid organic fertilizer.

3. A combination between Aspergillus niger and Pseudomonas putida with ratio of 1: 1 is the best supplemented culture condition to make the biofertilizer for manuring to chilies, tomatoes and eggplants.

The authors would like to thank the Institut for Research and Community Services (LPPM) of Institut Teknologi Sepuluh Nopember (ITS) on the Program (Pengabdian Kepada Masyarakat Berbasis Penelitian) for financial supporting with agreement document No: 983/PKS/ITS/2017.

\section{References}

1. I. Sigurnjak, C. Vaneeckhaute, E. Michels, B. Ryckaert, G. Ghekiere, F. M. G. Tack, E. Meers, Sci. Total Environ., 599-600 (2017).

2. European Commission, Study on the behaviour of digestate in agricultural soils. DG Environment, European Commission (2014).

3. A. Galvez, T. Sinicco, M. L. Cayuela, M. D. Mingorance, F. Fornasier, C. Mondini, Agric. Ecosyst. Environ., 160, 3-14 (2012).

4. P. Marbun, G. Hardy and P. J. Artha. Efektifitas Aspergillus niger dan Penicillium sp. dalam Meningkatkan Ketersediaan Fosfat dan Pertumbuhan Tanaman Jagung pada Tanah Andisol., Universitas Sumatera Utara (2013).

5. T. T. Yin, U. L. Pin, and A. H. A. Ghazali, Trop. Life Sci. Res., 26, 1 (2015)

6. S. Issar, and R. K. Gaur, Int. J. Adv. Res., 1, 8 (2013)

7. M. Day, M. Krzymien, K. Shaw, L. Zaremba, W.R. Wilson, C. Botden, and B. Thomas, Compost Sci. Util. 6, 2 (1998). 